\title{
Bone archives face prospect of dispersal
}

\section{Jim Giles, Cambridge}

In the days when the sun never set on the Empire, British ethnographers and anatomists freely collected skeletal remains from around the globe. But for years now, indigenous communities - especially those in Australia - have been asking for the remains of their ancestors back. And last week, a panel of academics and curators advised the British government to make legal changes that would open the way to such repatriations.

The panel, chaired by Norman Palmer, an expert in commercial law at University College London, said in its 5 November report that any remains should only be held with the consent of their direct descendants or leaders of a group of their descendants.

About half of the contents of Britain's two main collections of human remains - at the University of Cambridge and the Natural History Museum in London - originate from outside the country and would be subject to any new repatriation laws.

Aboriginal remains from Australia are likely to be among the first to be claimed back from Britain if the law is changed. Indigenous Australians argue that the remains were stolen, and want to lay them to rest in accordance with their cultural traditions. Specimens from Australian museums have already been returned.

The UK report is "a step towards true justice”, says Rodney Dillon of the Aboriginal and Torres Strait Islander Commission, an Australian group that campaigns for indigenous peoples' rights. "These remains were stolen. The remains are of human beings and they deserve to be buried like everyone else," Dillon says.

Researchers say they understand the campaigners' feelings, but that the break-up of the collections would undermine efforts to better understand human evolution and the history

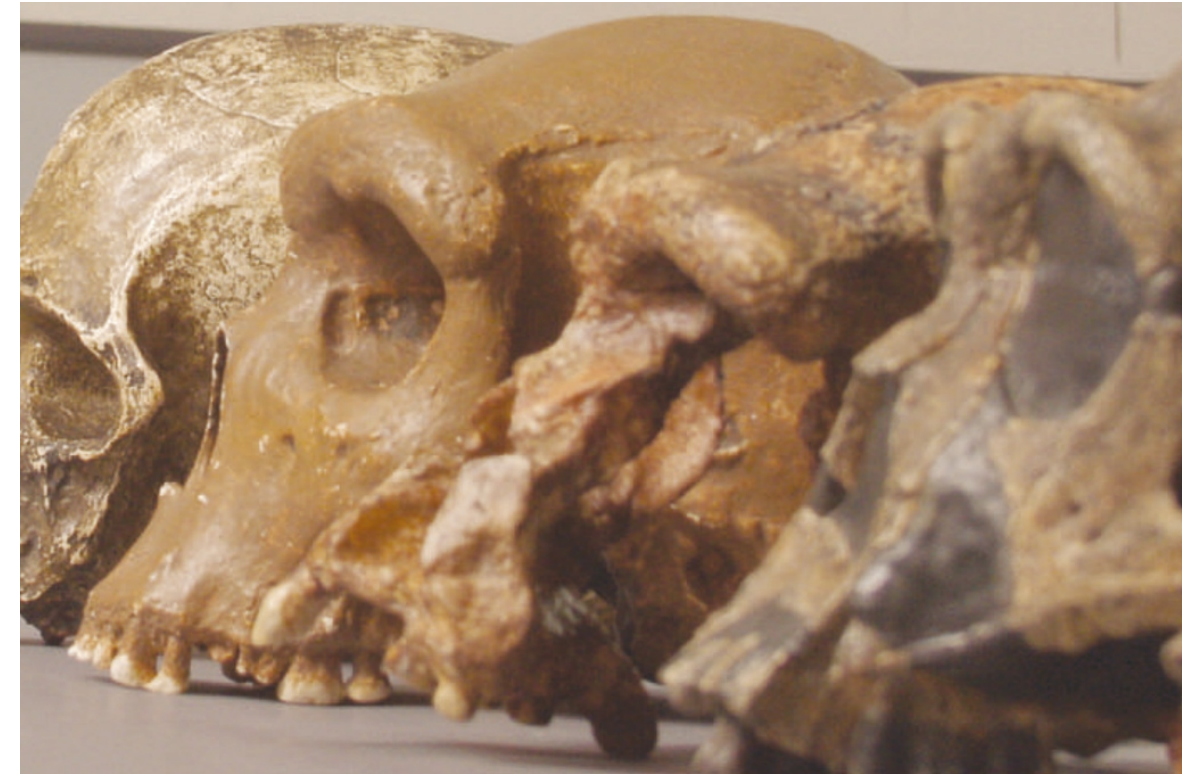

Heading home: skulls like these from the Duckworth collections may soon be joining their ancestors.

of the indigenous peoples themselves.

Marta Mirazón Lahr, an expert in human evolution and director of the Cambridgebased Duckworth collections, has used the bones in the collections to investigate how human appearance has changed over the past 100,000 years. The collections house the remains of more than 16,000 people, kept in rows of brown boxes. Neat black handwriting in yellowing books records the origin of each bone. "Skull of Aboriginal king, found in hollow of gum tree," reads a typical entry.

"These remains give us so much information about the diversity of people," says Lahr, who is dreading the implementation of the panel's findings. "This would be more than losing a few skulls. It would be like burning a library."

The government has pledged to respond to the report in January, and says it will consult with museums and universities before drafting any new legislation. But Tony Blair, the British prime minister, agreed in 2000 to cooperate with Australia over the repatriation of remains, and the political momentum appears to favour change.

In the United States, the 1990 Native American Graves Protection and Repatriation Act has led to fierce legal battles between indigenous groups and scientists over the use of human remains (see Nature 419, 5; 2002). It is unclear how many indigenous peoples from around the world would be interested in seeking the repatriation of remains from Britain's collections. Lahr says that most African objects in her collection are from Egypt, and she does not expect groups there to seek their repatriation.

\section{African states pledge increased spending on research}

\section{Michael Cherry, Cape Town}

Thirty-four African countries have committed themselves to spending at least $1 \%$ of their economic output on science and technology within five years.

The pledge was made in Johannesburg last week at the inaugural meeting of the ministerial council on science and technology, part of the New Partnership for Africa's Development (NEPAD) initiative.

Currently, Egypt is the only African country to spend $1 \%$ of its gross domestic product on research and development, although Algeria is close behind. South Africa, which will chair the ministerial council responsible for implementing the NEPAD science and technology programme, estimates its current spending at $0.7 \%$, and hopes this will rise to $1 \%$ within four years.

Wieland Gevers, president of the Academy of Science of South Africa, welcomed the announcement as "a huge step forward", but added that success "would depend on how purposefully funds were used".

Gevers hopes that the commitment will help attract aid from rich countries to support research in Africa - although he warned that Africans should not be junior partners in any resulting work. He said that an alliance of 10 African science academies will meet next month to consider how they can move towards the goal.

Biotechnology, science and technology for manufacturing, and energy and water research were among the 12 fields emphasized at the meeting. The aim is to create a centre of excellence in each field.

The African Laser Centre, which comprises a network of national laserresearch institutions, was launched at the conference. NEPAD is also backing the upgrading of existing centres, including the International Livestock Research Institute in Nairobi, to which the Canadian government last month committed US\$21 million. 